JOURNAL

of Health Inequalities

\title{
The Health Promotion Foundation's appeal on the International No Smoking Day 2018
}

\author{
Witold A. Zatoński \\ Health Promotion Foundation, Nadarzyn, Poland \\ European Observatory of Health Inequalities, the President Stanisław Wojciechowski State University of Applied Sciences \\ in Kalisz, Poland
}

ADDRESS FOR CORRESPONDENCE: Witold A. Zatoński, Health Promotion Foundation, 51 Mszczonowska Street, 05-830 Nadarzyn, Poland, phone: +48 2237800 22, e-mail: wazatonski@promocjazdrowia.pl

In the last three decades Poland has made remarkable progress in the fight against tobacco-related diseases [1]. At the beginning of the 1990s, the level of tobacco consumption in Poland was one of the highest in the world. Over 100 billion cigarettes were sold every year. Since then, smoking has dropped by over 50\%. By 2017 the consumption of cigarettes has dropped to about 40 billion pieces [2]. Since the Poles began to quit smoking on a mass scale, morbidity and mortality due to tobacco-related diseases, lung cancer, heart attacks, or chronic obstructive pulmonary disease, have also fallen sharply [1]. Over the period 1990-2017, mortality rate due to lung cancer among men aged 20-64 was halved [3].

However, Poland is still at the beginning of its path to achieving good health for all. Cigarettes are still smoked by about 8 million Polish men and women [1].

The 'Great Polish Smokeout' campaign, based on the the 'Great American Smokeout', has become one of the most important Polish anti-tobacco initiatives. This campaign has been co-ordinated in Poland since the begin-

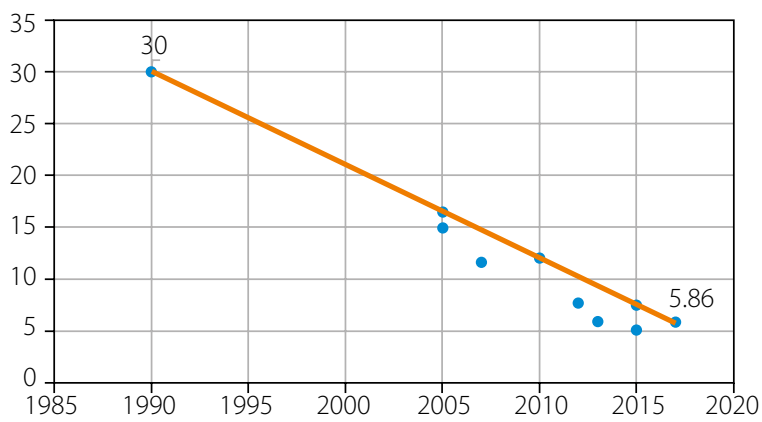

FIG. 1. Percentage of women smoking during pregnancy in Poland $[5,14]$ ning of the 1990s by the Health Promotion Foundation. Historically, it has been one of the most effective health promotion efforts in Poland. In its peak years, up to half a million of ex-smokers declared that they had quit smoking thanks to the 'Great Polish Smokeout'. As a result, millions of ex-smokers in Poland gained, on average, 10 years of life in good health [4].

From its very outset, one of the focal points of our campaign has been families expecting babies. On the one hand, the progress in the fight against smoking among pregnant women in Poland is remarkable - we have become the country with one of the lowest prevalence of smoking pregnant women. Research conducted in 1990, including all women giving birth in three voivodships: olsztyńskie, białostockie and poznańskie, showed that almost $30 \%$ of women smoked during pregnancy [5]. In 2017, 27 years later, in a study conducted on a nationwide sample, only $6 \%$ of pregnant women smoked cigarettes [6]. On the other hand, a $6 \%$ smoking prevalence among pregnant women means that about 25,000 infants have been directly exposed to tobacco smoke already in the womb. Scientific research has shown that more than $50 \%$ of carcinogens found in cigarette smoke penetrate the placenta. They are detected, among others, in the first sample of a newborn baby's urine. These infants are always born smaller, worse prepared for life, burdened with the risk of many diseases attributed to smoking, such as tumours or asthma. In addition, if a family member smokes cigarettes at home during the pregnancy, it leads to further exposure to tobacco smoke via passive smoking of the mother.

The Health Promotion Foundation appeals for families expecting babies to be the main focus of this year's International No Smoking Day, which falls on Thursday, Novem- 

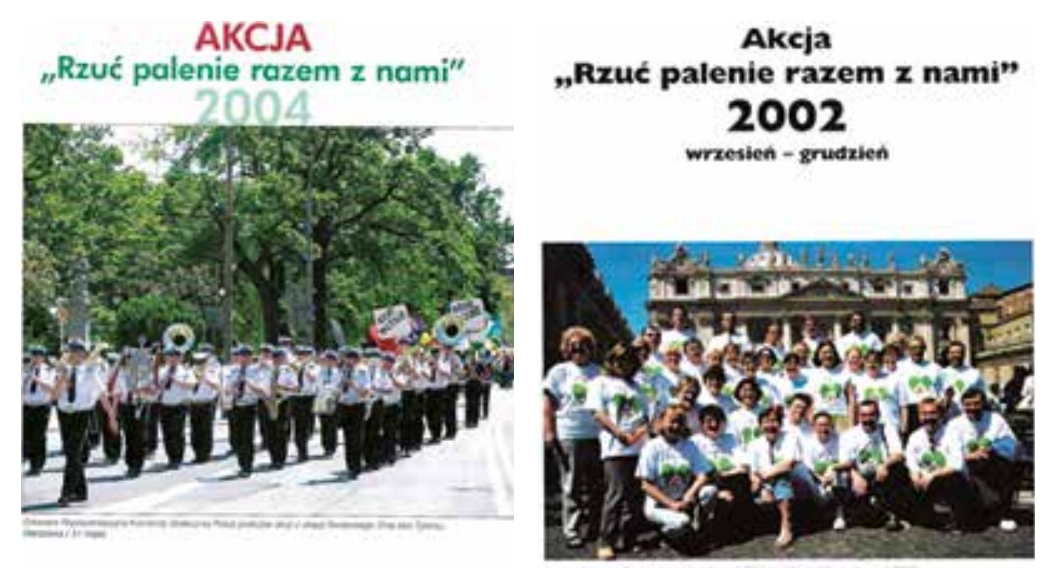

AKCJA

"Rzuć palenie razem z nami" 2005
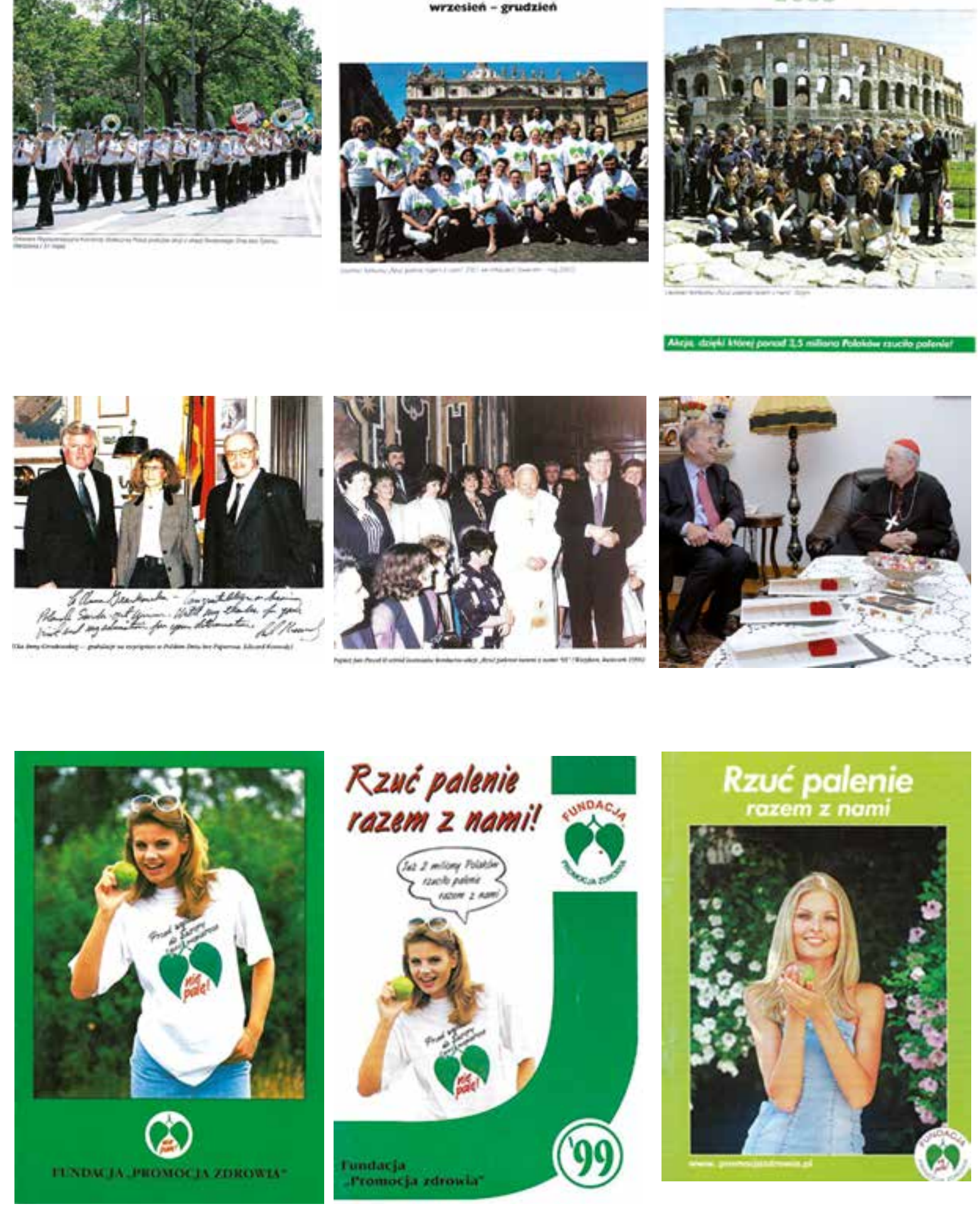
ber $15^{\text {th }}$. Children should be strictly protected against cigarette smoke. We appeal to all Poles, Polish organisations and institutions, and any recipients of this appeal, including yourself, to support the campaign and offer assistance in quitting smoking to families expecting babies.

\section{DISCLOSURE}

The author reports no conflict of interest.

\section{References}

1. Zatoński WA, Zatoński M. Poland's rapid lung cancer decline in the years 1990-2016. The first step towards the eradication of lung cancer in Poland. Health Prob Civil 2017; 11: 211-225.

2. Zatoński WA, Zatoński M, Janik-Koncewicz K, et al. Hundred years of cigarette smoking in Poland: three phases of the tobacco epidemic. J Health Inequal 2017; 3: 118-122.

3. Zatoński WA, Tukiendorf A and HPF team. Lung cancer mortality decline among middle-aged men and women in Poland and the UK. J Health Inequal 2017; 3: 123-126.

4. Zatoński W. Droga do zdrowia. Historia przeciwdziałania chorób odtytoniowych w Polsce. Fundacja Promocja Zdrowia”, Warszawa 2004.

5. Szamotulska K, Brzeziński ZJ. Palenie tytoniu przez kobiety ciężarne a stan biologiczny noworodka w Polsce. Alkohol Narkom 2000; 13: 389-398.

6. Państwowa Inspekcja Sanitarna. Raport z badania - zachowania zdrowotne kobiet w ciąży. Warszawa 2017. Available from: https://gis.gov.pl/wp-content/uploads/2018/04/Zachowania -zdrowotne-kobiet-w-ci\%C4\%85\%C5\%BCy-alkohol-i-papierosy.-Raport-2017-1.pdf (accessed: 17 September 2018).

7. Adamek R, Florek E, Piekoszewski W, et al. Wpływ narażenia na dym tytoniowy oraz wybranych czynników społeczno-ekonomicznych na występowanie małej urodzeniowej masy ciała. Przegl Lek 2005; 62: 965-969.

8. Wierzejska R, Jarosz M, Sawicki W, et al. Antyzdrowotne zachowania kobiet ciężarnych. Tytoń, alkohol, kofeina. Żyw Człow 2011; 38: 84-98.

9. Pirogowicz I, Gryboś-Jagielska A, Patyk M, et al. Narażenie kobiet w ciąży na dym tytoniowy - badania porównawcze w odstępie 5-letnim (2005 i 2010 r.). Fam Med Prim Care Rev 2012; 14: 417-419.

10. Wojtyła C, Wojtyła-Buciora P. Cigarette smoking among pregnant women in Poland. J Health Inequal 2017; 3: 47-50.

11. Korzeniowska K, Cieślewicz A, Pawlaczyk M, et al. Postawy kobiet ciężarnych i ich otoczenia wobec nałogu palenia tytoniu. Farmacja Współczesna 2013; 6: 163-167.

12. Adamek R, Adamek AM, Zysnarska M, et al. Palenie papierosów w ciąży i nadciśnienie tętnicze - najsilniejszymi determinantami małej urodzeniowej masy ciała noworodków. Hygeia Public Health 2013; 49: 279-283.

13. Instytut Medycyny Wsi im. Witolda Chodźki. Raport „Zachowania zdrowotne kobiet w ciąży”. Lublin, 2013. Available from: https://www.ciazabezalkoholu.pl/images/file/RozpowszechnianieFASD/Zachowania.pdf (accessed: 17 September 2018).

14. Lange S, Probst Ch, Rehm J, Popova A. National, regional, and global prevalence of smoking during pregnancy in the general population: a systematic review and meta-analysis. Lancet Glob Health 2018; 6: e769-e776. 